\title{
Acceptance and Use of Complementary and Alternative Medicine Among Medical Specialists: A Systematic Review and Meta-analysis
}

Phanupong Phutrakool

Chulalongkorn University Faculty of Medicine

Krit Pongpirul ( $\nabla$ doctorkrit@gmail.com )

Chulalongkorn University Faculty of Medicine https://orcid.org/0000-0003-3818-9761

\section{Research}

Keywords: Acceptance, Use, Complementary and Alternative Medicine, Medical specialist

Posted Date: February 10th, 2021

DOI: https://doi.org/10.21203/rs.3.rs-215114/v1

License: (1) This work is licensed under a Creative Commons Attribution 4.0 International License. Read Full License 


\section{Abstract}

Background

Complementary and Alternative Medicine (CAM) has gained popularity among the general population but its acceptance and use among medical specialists have been inconclusive.

Methods

We conducted a systematic literature search in PubMed and Scopus databases for the acceptance and use of CAM among medical specialists. Each article was assessed by two screeners. Only survey studies relevant to the acceptance and use of CAM among medical specialists were reviewed. The pooled prevalence estimates were calculated using random-effects meta-analyses.

Results

Of 5,628 articles published between 2002 and 2017, 25 fulfilled the selection criteria. Ten medical specialties were included: Internal Medicine (11 studies), Pediatrics (6 studies), Obstetrics and Gynecology (6 studies), Anesthesiology (4 studies), Surgery (3 studies), Family Medicine (3 studies), Physical Medicine and Rehabilitation (3 studies), Psychiatry and Neurology (2 studies), Otolaryngology (1 study), and Neurological Surgery ( 1 study). The overall acceptance of CAM was 52\% (95\% Cl: 42-62\%). Family Medicine reported the highest acceptance $(67 \% ; 95 \% \mathrm{Cl}$ : $60-73 \%)$, followed by Psychiatry and Neurology (64\%; $95 \% \mathrm{Cl}: 35-85 \%)$, Neurological Surgery $(63 \% ; 95 \% \mathrm{Cl}: 43-79 \%)$, Obstetrics and Gynecology (62\%; 95\% Cl: 36-82\%), Pediatrics (60\%; 95\% Cl: 41-77\%), Anesthesiology (52\%; 95\% Cl: 45-58\%), Physical Medicine and Rehabilitation (51\%; $95 \% \mathrm{Cl}: 42-61 \%)$, Internal Medicine $(41 \% ; 95 \% \mathrm{Cl}: 39-43 \%)$, and Surgery $(26 \% ; 95 \% \mathrm{Cl}: 22-30 \%)$. The overall use of CAM was $45 \%(95 \% \mathrm{Cl}$ : $37-$ $54 \%)$. The highest use of CAM was by the Obstetrics and Gynecology $(68 \% ; 95 \% \mathrm{Cl}: 63-73 \%)$, followed by Family Medicine $(63 \% ; 95 \% \mathrm{Cl}$ : $58-$ $68 \%)$, Psychiatry and Neurology (55\%; 95\%Cl: 35-73\%), Pediatrics (44\%; 95\% Cl: 42-46\%), Otolaryngology (43\%; 95\%Cl: 30-57\%), Anesthesiology (42\%; 95\% Cl: 37-47\%), Internal Medicine (38\%; 95\%Cl: 36-41\%), Physical Medicine and Rehabilitation (32\%; 95\%Cl: 24-41\%), and Surgery (25\%; $95 \% \mathrm{Cl}: 22-29 \%)$. Based on the studies, meta-regression showed no statistically significant difference across geographic regions, economic levels of the country, or sampling methods.

Conclusion

Acceptance and use of CAM were moderate and varied across medical specialists.

Systematic review registration

This systematic review has been registered in PROSPERO (CRD42019125628) and the protocol can be accessed at

http://www.crd.york.ac.uk/PROSPERO/display_record.asp?ID=CRD42019125628.

\section{Background}

Medical specialist is a healthcare professional who has undertaken specialized medical studies to diagnose, treat and prevent illness, disease, injury, and other physical and mental impairments in humans, using specialized testing, diagnostic, medical, surgical, physical and psychiatric techniques, through application of the principles and procedures of modern medicine [1].

Complementary and Alternative Medicine (CAM) is defined as medicine or treatment which is not considered as conventional (standard) medicine. National Center for Complementary and Integrative Health $(\mathrm{NCClH})$ categorized most types of complementary medicines under two categories: (1) natural products, and (2) mind-body practices [2]. Natural products include herbs, vitamins, minerals, and probiotics whereas mind-body practices include yoga, chiropractic, massage, acupuncture, yoga, meditation, and massage therapy. Types of CAM may vary across studies, but they overlap in most senses.

CAM is used by people throughout the world. A study showed that the prevalence estimate of CAM usage from 32 countries from all regions of the world to be $26.4 \%$, ranging from $25.9 \%$ to $26.9 \%$. For example, in 2013 , the prevalence use of CAM in Australia, the USA, United Kingdom and China were $34.7 \%, 21.0 \%, 23.6 \%$, and $53.3 \%$, respectively. The prevalence estimate of CAM satisfaction was as high as $71.9 \%$, ranging from $71.0 \%$ to $72.7 \%$ [3]. Although patients are highly satisfied with CAM treatment, however, professional health care providers who are medical doctors do not offer CAM because it is not part of the standard medical care services. A study showed that less than $20 \%$ of the medical doctors were very comfortable in answering questions about CAM [4] so patients who do not have the option to use CAM instead of standard medical care will be lost to follow-up. 
In the field of oncology, the 5-year survival rate of breast cancer patients who refused standard treatment was $43.2 \%$ (95\% $\mathrm{Cl} 32.0-54.4$ ) whereas for those who underwent the standard treatment, it was 81.9\% (95\% Cl 76.9-86.9) [5]. When CAM was used, the 5-year survival rate was worse. The 5-year survival rate of cancer patients who used CAM versus those who used standard treatment were stratified by cancer type were as follows: [6] for Breast cancer 58.1\% (95\% Cl: 46.0-68.5) vs 86.6\% (95\% Cl: 80.7-90.7), p-value < 0.01; HR = 5.68 (95\% Cl: 3.22-10.04), Lung cancer $19.9 \%$ (95\% Cl: 9.9-32.4) vs 41.3\% (95\% Cl: 31.1-51.2), p-value < 0.01; HR = 2.17 (95\% Cl: 1.42-3.32), and Colorectal cancer 32.7\% (95\% Cl: 15.8-50.8) vs 79.4\% (95\% Cl: 66.3-87.8), p-value < 0.01; HR $=4.57$ (95\% Cl: 1.66-12.61). Interestingly, this was not the case for those who had prostate cancer. The 5-year survival rate for patients with prostate cancer who used CAM versus the standard treatment was $86.2 \%$ (95\% Cl: 73.9-92.9) vs 91.5\% (95\% Cl: 84.7-95.4), p-value = 0.36; $\mathrm{HR}=1.68$ (95\% Cl: 0.68-4.17).

The 28-day mortality of patient with Sepsis and Acute gastrointestinal injury (AGI) who received CAM bundle with conventional therapy was statistically significantly lower than those who received only conventional therapy $(21.2 \%$ vs $32.5 \%, p-v a l u e=0.038)$ [7].

There are few studies that have investigated the acceptance and use of CAM. Aside from that, previous studies could not compare the use of CAM across medical specialties. Also, many studies could not determine the effect of specialist, use of CAM by region and economic level of the country, survey method, and sampling method.

This systematic review and meta-analysis aimed to identify studies that have accepted and used CAM among medical specialists. The selected studies must quantify the number of acceptance or usage of CAM by medical specialist.

\section{Materials And Methods}

\section{Protocol and registration}

This systematic review has been registered in PROSPERO (CRD42019125628) and the protocol can be accessed at http://www.crd.york.ac.uk/PROSPERO/display_record.asp?ID=CRD42019125628.

\section{Literature search}

This systematic review and meta-analysis were conducted and reported according to the PRISMA statement guidelines. A systematic literature search was performed by two independent authors (PP and KP) using PubMed and Scopus databases. The search was limited to observational studies of human subjects and the English language. The medical specialist's perspective related to CAM studies were focused. The search strategy was based on various combinations of words and focused on two main concepts: acceptance and usage of CAM. The last search was conducted on March 1, 2019.

For the PubMed database, the following combinations were applied: ("Traditional Medicine"[All Fields] OR "Alternative Medicine"[All Fields] OR "Complementary Medicine"[All Fields] OR "Acupuncture Therapy"[All Fields] OR "Holistic Health"[All Fields] OR "Homeopathy"[All Fields] OR "Spiritual Therapies"[All Fields] OR "Faith Healing"[All Fields] OR "Yoga"[All Fields] OR "Witchcraft"[All Fields] OR "Shamanism"[All Fields] OR "Meditation"[All Fields] OR "Aromatherapy"[All Fields] OR "Medical Herbalism"[All Fields] OR "Mind-Body Therapies"[All Fields] OR "Laughter Therapy"[All Fields] OR "Hypnosis"[All Fields] OR "Tai Ji"[All Fields] OR "Tai Chi"[All Fields] OR "Relaxation Therapy"[All Fields] OR "Mental Healing"[All Fields] OR "Meditation"[All Fields]) AND ("Health care provider"[All Fields] OR "Health care providers"[All Fields] OR "Health personnel"[All Fields]) AND ("2002/01/01"[PDAT] : "2017/12/31"[PDAT]) AND "humans"[MeSH Terms].

For the Scopus database, the following combinations were applied: (ALL("Traditional Medicine") OR ALL("Alternative Medicine") OR ALL("Complementary Medicine") OR ALL("Acupuncture Therapy") OR ALL("Holistic Health") OR ALL("Homeopathy") OR ALL("Spiritual Therapies") OR ALL("Faith Healing") OR ALL("Yoga") OR ALL("Witchcraft") OR ALL("Shamanism") OR ALL("Meditation") OR ALL("Aromatherapy") OR ALL("Medical Herbalism") OR ALL("Mind-Body Therapies") OR ALL("Laughter Therapy") OR ALL("Hypnosis") OR ALL("Tai Ji") OR ALL("Tai Chi") OR ALL("Relaxation Therapy") OR ALL("Mental Healing") OR ALL("Meditation")) AND (ALL("Health care provider") OR ALL("Health care providers") OR ALL("Health personnel")) AND PUBYEAR AFT 2001 AND PUBYEAR BEF 2018 AND DOCTYPE(ar) AND INDEXTERMS("Humans")

\section{Selection of studies}

The titles and abstracts of the primary studies identified in the electronic search were screened by the same two authors. Duplicated studies were excluded. For the meta-analysis, the following inclusion criteria were set: (1) medical specialist's perspective, (2) prevalence of acceptance or usage of CAM, (3) observational study design, and (4) published between 2002 to 2017. The following exclusion criterion was set: (1) Not relevant to the practice. We contacted the authors for studies that had incomplete and unclear information. If the authors did not respond within 14 days, we proceeded to analyze the data we had. Any disagreement was resolved through discussion and the final determination was made by the first author (PP). 
Two authors worked independently to review and extract the following variables: (1) general information, including the name of the studies, authors, and publication year, (2) characteristics of the studies, including the design of the studies, sampling method, country, and setting, (3) characteristics of the participants, including sample size, response, and type of specialty, and (4) outcomes, including the prevalence of acceptance, and usage of CAM. All relevant text, tables, and figures were examined for data extraction. Discrepancies between the two reviewers were resolved by the first author (PP).

\section{Study quality/Risk of bias}

We used the tool developed by Hoy et al [8] to evaluate the study quality/risk of bias of the studies included in the analysis. The tool has 11 items: (1) national representativeness, (2) target population representativeness, (3) random selection or census undertaken, (4) minimal nonresponse bias, (5) data collection direct from the subject, (6) definition of the case used, (7) valid and reliable instrument, (8) same mode of data collection for all subjects, (9) length of shortest prevalence period, (10) appropriate numerator and denominator used, and (11) summary assessment. Items 1 to 4 assessed the external validity, items 5 to 10 assessed the internal validity, and items 11 evaluated the overall study quality/risk of bias. Each item was assigned a score of 1 (High quality/Low risk) or 0 (Low quality/High risk), and the scores were summed to generate an overall quality score that ranged from 0 to 10 . According to the overall score, we classified the studies as having a high quality/low risk of bias (>6), moderate quality/risk of bias (4 to 6), and low quality/high risk of bias (<4). Two authors (PP and KP) independently assessed the study quality/risk of bias and any disagreement was resolved by discussion and consensus.

\section{Conflict of interest}

We assessed the conflict of interest of the authors' declarations in the studies.

\section{Statistical analysis}

Unadjusted prevalence estimates of acceptance and usage of CAM were calculated based on the information of crude numerators and denominators provided by the studies and medical specialty [9]. Pooled prevalence was estimated from the prevalence as reported by the eligible studies. Forest plots were generated displaying the prevalence with a $95 \% \mathrm{Cl}$ for each study. The overall random-effects pooled estimate with its $95 \% \mathrm{Cl}$ were reported. To examine the magnitude of the variation between the studies, we quantified the heterogeneity by using $P^{2}$ and its $95 \% \mathrm{Cl}$.

To assess the level of heterogeneity as defined in Chapter 9 of the Cochrane Handbook for Systematic Reviews of Interventions, the following $P$ cut-offs for $0 \%$ to $40 \%$ represented that the heterogeneity may not be important, $30 \%$ to $60 \%$ may represent moderate heterogeneity, $50 \%$ to $90 \%$ may represent substantial heterogeneity, $75 \%$ to $100 \%$ represented that there was a considerable heterogeneity. For the $X^{2}$ test, statistical heterogeneity of the included trials was assessed with a p-value of less than 0.05 (statistically significant). The random-effects meta-analysis by DerSimonian and Laird method was used, and statistical heterogeneity was encountered. The meta-analysis was performed using Stata/MP software version 15 (StataCorp 2017, College Station, TX).

\section{Additional Analysis}

Meta-regression was performed to investigate the pooled prevalence differences between various regions (African region, region of the Americas, Eastern Mediterranean region, European region, Southeast Asia region, Western Pacific region, and mixed region) [10], economic levels of the country (low-income, lower-middle-income, upper-middle-income, high-income, and mixed-income) [11], and the sampling method (random and convenience sampling).

\section{Results}

\section{Selection of the studies}

The literature search yielded 5,628 articles. After 794 duplicates were removed, 4,831 titles and abstracts were screened, and 4,719 irrelevant articles were removed. Of 115 articles selected for full-text screening, 62 were excluded for the following reasons: two were not relevant to this study's objective, 17 had the wrong target population, 22 did not have the study design required for this review, two study was not published in English, 19 did not have full-text available, and 28 did not provide the prevalence. Finally, a total of 25 articles, published between 2002 and 2017 , fulfilled the selection criteria and were included in this meta-analysis (Fig 1).

\section{Characteristics of the studies}


All included studies were cross-sectional. The publication years ranged from 2002 to 2017 in various countries: European region ( $\mathrm{n}=11$, $44 \%)$, region of the Americas ( $n=10,40 \%)$, Western Pacific region $(n=3,12 \%)$, and mixed region $(n=1,4 \%)$. Twenty-three studies $(88 \%)$ were from high-income countries, 2 (8\%) from upper-middle income countries, and 1 (4\%) was from mixed-economic level country. The included studies indicated which type of collection method was used: online survey $(n=8,32 \%)$, postal survey $(n=8,32 \%)$, online and postal survey ( $n=$ $3,12 \%)$, online and phone survey $(n=1,4 \%)$, and the collection method was not reported $(n=5,20 \%)$. The studies included a total of 7,320 participants who were categorized as medical specialty $(n=5,445,74 \%)$, and non-medical specialty $(n=1,875,26 \%)($ Table 1$)$.

The included studies had the following medical specialties: Internal Medicine (11 studies, $n=2,253$ ), Pediatrics (6 studies, $n=2,130)$, Obstetrics and Gynecology (6 studies, $n=707$ ), Anesthesiology (4 studies, $n=342$ ), Surgery (3 studies, $n=564)$, Family Medicine (3 studies, $n=296$ ), Physical Medicine and Rehabilitation (3 studies, $n=104)$, Psychiatry and Neurology (2 studies, $n=22)$, Otolaryngology $(1$ study, $n=49)$, and Neurological Surgery (1 study, $n=24)($ Table 2).

\section{Based on the Specialty}

\section{Prevalence of CAM acceptance}

The overall random-effect pooled prevalence of CAM acceptance in medical specialty was 52\% (95\% Cl:42-62\%). The prevalence of CAM acceptance in Family Medicine was 67\% (95\% Cl:60-73\%), Psychiatry and Neurology was 64\% (95\% Cl:35-85\%), Neurological Surgery was 63\% (95\% Cl:43-79\%), Obstetrics and Gynecology was 62\% (95\% Cl:36-82\%), Pediatrics was 60\% (95\% Cl:41-77\%), Anesthesiology was 52\% (95\% Cl:45-58\%), Physical Medicine and Rehabilitation was 51\% (95\% Cl:42-61\%), Internal Medicine was 41\% (95\% Cl:39-43\%), and Surgery was 26\% (95\% Cl:22-30\%). The overall heterogeneity was significant $\left(\mathrm{I}^{2}=94.99 \%\right.$, p-value $\left.<0.001\right)($ Fig 2$)$.

\section{Prevalence of CAM usage}

The overall random-effect pooled prevalence of CAM usage in medical specialty was 45\% (95\% Cl:37-54\%). The prevalence of CAM usage in Obstetrics and Gynecology was 68\% (95\% Cl:63-73\%), Family Medicine was 63\% (95\% Cl:58-68\%), Psychiatry and Neurology was 55\% (95\% Cl:35-73\%), Pediatrics was 44\% (95\% Cl:42-46\%), Otolaryngology was 43\% (95\% Cl:30-57\%), Anesthesiology was 42\% (95\% Cl:37-47\%), Internal Medicine was 38\% (95\% Cl:36-41\%), Physical Medicine and Rehabilitation was 32\% (95\% Cl:24-41\%), and Surgery was 25\% (95\% Cl:22-29\%). The overall heterogeneity was significant $\left(I^{2}=94.90 \%\right.$, $\mathrm{p}$-value $\left.<0.001\right)$ (Fig 3).

\section{Based on the studies}

\section{Prevalence of CAM acceptance}

The overall random-effect pooled prevalence of CAM acceptance was 54\% (95\% Cl:36-73\%) (Fig 4, upper left side). Twelve studies provided CAM acceptance: five studies in the European region, five studies in the region of the Americas, and two studies in the Western Pacific region. The pooled prevalence of the European region, region of the Americas, and Western Pacific region that accepted CAM were 60\% (95\% Cl:3683\%), 54\% (95\% Cl:39-68\%), and 20\% (95\% Cl:17-22\%), respectively (Fig 4, upper right side). All 12 studies were done in high-income economic countries (Fig 4, lower left side). Based on the sampling method, the pooled prevalence of random sampling method, and non-random sampling method were 54\% (95\% Cl:30-77\%), and 55\% (95\% Cl:44-67\%), respectively (Fig 4, lower right side). The overall heterogeneity was significant $\left(I^{2}=99.14 \%\right.$, $p$-value $\left.<0.001\right)$ as was the between-group heterogeneity $(p$-value $<0.001)$.

Meta-regression showed that there were no significant differences in the pooled prevalence of CAM acceptance by region, economic levels of the country, and the sampling method (Table 3).

\section{Prevalence of CAM usage}

The overall random-effect pooled prevalence of CAM usage was 52\% (95\% Cl:42-62\%) (Fig 5, upper left side). Twenty-one studies provided CAM usage information: nine studies in the European region, eight studies in the region of the Americas, three studies in the Western Pacific region, and one study in the mixed region. The pooled prevalence of European region, region of the Americas, Western Pacific region, and mixed region that used CAM were 54\% (95\% Cl:37-71\%), 59\% (95\% Cl:46-73\%), 37\% (95\% Cl:18-56\%), and 18\% (95\% Cl:11-27\%), respectively (Fig 5, upper right side). All 18 studies were conducted in high-income economic countries, two studies were conducted in upper-middle-income economic countries, and one study was conducted in a mixed-income economic country. The pooled prevalence of high-income economic countries, upper-middle-income economic, and mixed-income economic countries that used CAM was 52\% (95\% Cl:41-62\%), 74\% (95\% Cl:67$80 \%$ ), and 18\% (95\% Cl:11-27\%), respectively (Fig 5, lower left side). Based on the sampling method, the pooled prevalence of the random sampling method, and non-random sampling method were 51\% (95\% Cl:39-64\%), and 54\% (95\% Cl:38-70\%) respectively (Fig 5, lower right side). The overall heterogeneity was significant $\left(I^{2}=98.29 \%\right.$, $p$-value $\left.<0.001\right)$ as was between-group heterogeneity ( $p$-value $\left.<0.001\right)$ 
Meta-regression showed that there were no significant differences in the pooled prevalence of CAM usage by region, economic levels of the country, and the sampling method (Table 3).

\section{Assessment of study quality/risk of bias/conflict of interest}

A total of 24 (96\%) studies were categorized as high quality/low risk of bias, whereas one (4\%) was categorized as moderate quality/moderate risk of bias. No study met the criteria of low quality/high risk of bias (Fig 6). Only five studies (20\%) declared that there were conflicts of interest.

\section{Discussion}

This study is the first of its kind to compare the acceptance and usage of CAM across various medical specialties. Nearly three-quarters of the specialties accepted CAM whereas nearly a third were using CAM.

The synthesis of all prevalence estimates of acceptance and usage was $52 \%$ and $45 \%$, respectively. The highest prevalence of acceptance was in Family Medicine, followed by Psychiatry and Neurology, Neurological Surgery, Obstetrics and Gynecology, Pediatrics, Anesthesiology, Physical Medicine and Rehabilitation, Internal Medicine, and Surgery. The highest prevalence of usage was in Obstetrics and Gynecology, followed by Family Medicine, Psychiatry and Neurology, Pediatrics, Otolaryngology, Anesthesiology, Internal Medicine, Physical Medicine and Rehabilitation, and Surgery. These findings were useful in terms of improving care plan, decision-making processes, and communication in terms of CAM between the doctors and the patients.

All of the medical specialties mentioned above had a higher prevalence of acceptance than the prevalence of CAM use, except for Obstetrics and Gynecology because the gynecologic oncologists have used CAM to treat a large number of breast cancer patients [12]. There was a small difference in the prevalence ( $<5 \%)$ between the acceptance and the usage in Family Medicine (4\%), Obstetrics and Gynecology (4\%), Internal Medicine (3\%), and Surgery (1\%).

A highest difference of prevalence of CAM acceptance and usage was in the field of Physical Medicine and Rehabilitation (19\%). This difference may be due to the reduction in the use of acupuncture in the academic hospitals [13] as well as personal use. Nearly two-thirds of the rehabilitation physicians advised against the use of CAM as a therapeutic option [14]. The lowest prevalence of acceptance and usage of CAM was observed in Surgery. This relatively low prevalence compared to other medical specialties may be due to the belief that CAM products were ineffective. Many surgeons lacked information regarding CAM usage.

From the meta-analysis, it showed that the acceptance of CAM was neutral in European region, and region of the Americas. The World Health Organization reported that the prevalence of CAM usage in the European region, region of the Americas, and Western Pacific region in 2018 was $89 \%, 80 \%$, and $95 \%$, respectively [10], while this review found that the corresponding prevalence was $54 \%$, $59 \%$, and $37 \%$, respectively. The lower prevalence may be from the dominating studies that were conducted before 2010 whereas CAM has used more often after 2010.

The variation of prevalence of CAM used was investigated in relation to the economic level of the countries. There was a higher prevalence of CAM use in the upper-middle-income economies than the high-income economies which may be due to cultural, historical influences, and implementation of CAM in the national health system as seen in Brazil [15] and Mexico [16].

Our study has some limitations that should be considered when interpreting the findings. All studies included did not cover some medical specialties that might have different acceptance and usage of CAM. Therefore, the prevalence of acceptance and usage of CAM in these populations need to be confirmed by further studies. The prevalence of acceptance in some specialties like Neurological Surgery, Obstetrics and Gynecology, Otolaryngology, Pediatrics, and Psychiatry and Neurology was reported by a single study, thus limiting the generality of such findings.

High heterogeneity of acceptance and usage of CAM between medical specialty referred to the variation in professional characteristic and practice, measurement methods, and study questionnaire. Most of the studies were from high-income economic countries. There were no studies from low-middle, and low-income economic countries which is of concern.

We found that no studies compared the relevant demographic characteristics between the responders and non-responders that would increase non-response bias when estimating the prevalence of CAM use. Although most of the studies demonstrated low risk of bias, over $88 \%$ of the studies did not use a validated instrument. Finally, the conflict of interest was not declared in more than $80 \%$ of the studies which may result in unintentional bias in the collection, analysis, and interpretation of the data. This can consequently lead to claims that the CAM used was beneficial because the researcher and/or entity may have a financial or management interest in the CAM used.

\section{Declarations}


Ethics approval and consent to participate

Not applicable.

Consent for publication

Not applicable.

Availability of data and materials

All data generated or analysed during this study are included in this published article.

Competing interests

The authors declare that they have no competing interest.

Funding

This study received financial support from the Ratchadapiseksompotch Fund, Faculty of Medicine, Chulalongkorn University (Grant Number RA62/059), and Department of Thai Traditional and Alternative Medicine, Ministry of Public Health. The sponsors have no involvement in the systematic search, abstract screening, data extraction, or manuscript preparation.

\section{Authors' contributions}

Phutrakool P conceptualized and designed the study, collected the data, analyzed and interpreted the data, drafted the article, and finalized the manuscript for submission. Pongpirul K conceptualized and designed the study, collected the data, analyzed and interpreted the data, drafted the article, and finalized the manuscript for submission.

\section{Acknowledgements}

We thank Dr. Kulthanit Wanaratna and Dr. Monthaka Teerachaisakul of the Department of Thai Traditional and Alternative Medicine, Ministry of Public Health for their administrative supports.

\section{References}

1. WHO European health information at your fingertips [https://gateway.euro.who.int/en/indicators/hlthres_242-specialist-medicalpractitioners-total/]

2. Complementary, Alternative, or Integrative Health: What's In a Name? [https://nccih.nih.gov/health/integrative-health]

3. Peltzer K, Pengpid S: Prevalence and determinants of traditional, complementary and alternative medicine provider use among adults from 32 countries. Chinese journal of integrative Medicine 2018, 24(8):584-590.

4. Stub T, Quandt SA, Arcury TA, Sandberg JC, Kristoffersen AE: Complementary and conventional providers in cancer care: experience of communication with patients and steps to improve communication with other providers. BMC complementary and alternative medicine 2017, 17(1):301.

5. Joseph K, Vrouwe S, Kamruzzaman A, Balbaid A, Fenton D, Berendt R, Yu E, Tai P: Outcome analysis of breast cancer patients who declined evidence-based treatment. World J Surg Oncol 2012, 10:118.

6. Johnson SB, Park HS, Gross CP, Yu JB: Use of alternative medicine for cancer and its impact on survival. JNCl: Journal of the National Cancer Institute 2018, 110(1):121-124.

7. Xing X, Zhi Y, Lu J, Lei S, Huang L, Zhu M, Fang K, Wang Q, Wu J, Wu Y: Traditional Chinese medicine bundle therapy for septic acute gastrointestinal injury: A multicenter randomized controlled trial. Complementary therapies in medicine 2019, 47:102194.

8. Hoy D, Brooks P, Woolf A, Blyth F, March L, Bain C, Baker P, Smith E, Buchbinder R: Assessing risk of bias in prevalence studies: modification of an existing tool and evidence of interrater agreement. Journal of Clinical Epidemiology 2012, 65(9):934-939.

9. ABMS Guide to Medical Specialties [https://www.abms.org/member-boards/specialty-subspecialty-certificates/]

10. WHO Global Report on Traditional and Complementary Medicine 2019 [https://apps.who.int/iris/bitstream/handle/10665/312342/9789241515436-eng.pdf]

11. World Bank Country and Lending Groups [https://datahelpdesk.worldbank.org/knowledgebase/articles/906519-world-bank-country-andlending-groups] 
12. Klein E, Beckmann MW, Bader W, Brucker C, Dobos G, Fischer D, Hanf V, Hasenburg A, Jud SM, Kalder M et al: Gynecologic oncologists' attitudes and practices relating to integrative medicine: results of a nationwide AGO survey. Archives of gynecology and obstetrics 2017 , 296(2):295-301.

13. Mann B, Burch E, Shakeshaft C: Attitudes Toward Acupuncture Among Pain Fellowship Directors. Pain medicine (Malden, Mass) 2016, 17(3):494-500.

14. Mak JC, Mak LY, Shen Q, Faux S: Perceptions and attitudes of rehabilitation medicine physicians on complementary and alternative medicine in Australia. Internal medicine journal 2009, 39(3):164-169.

15. Samano ES, Ribeiro LM, Campos AS, Lewin F, Filho ES, Goldenstein PT, Costa LJ, del Giglio A: Use of complementary and alternative medicine by Brazilian oncologists. European journal of cancer care 2005, 14(2):143-148.

16. Brambila-Tapia AJ, Rios-Gonzalez BE, Lopez-Barragan L, Saldana-Cruz AM, Rodriguez-Vazquez K: Attitudes, Knowledge, Use, and Recommendation of Complementary and Alternative Medicine by Health Professionals in Western Mexico. Explore (New York, NY) 2016, 12(3):180-187.

17. Rosenbaum ME, Nisly NL, Ferguson KJ, Kligman EW: Academic physicians and complementary and alternative medicine: an institutional survey. American journal of medical quality : the official journal of the American College of Medical Quality 2002, 17(1):3-9.

18. Hyodo I, Eguchi K, Nishina T, Endo H, Tanimizu M, Mikami I, Takashima S, Imanishi J: Perceptions and attitudes of clinical oncologists on complementary and alternative medicine: a nationwide survey in Japan. Cancer 2003, 97(11):2861-2868.

19. Kemper KJ, O'Connor KG: Pediatricians' recommendations for complementary and alternative medical (CAM) therapies. Ambulatory pediatrics : the official journal of the Ambulatory Pediatric Association 2004, 4(6):482-487.

20. Kolstad A, Risberg T, Bremnes Y, Wilsgaard T, Holte H, Klepp O, Mella O, Wist E: Use of complementary and alternative therapies: a national multicentre study of oncology health professionals in Norway. Supportive care in cancer : official journal of the Multinational Association of Supportive Care in Cancer 2004, 12(5):312-318.

21. Risberg T, Kolstad A, Bremnes Y, Holte H, Wist EA, Mella O, Klepp O, Wilsgaard T, Cassileth BR: Knowledge of and attitudes toward complementary and alternative therapies; a national multicentre study of oncology professionals in Norway. European journal of cancer (Oxford, England: 1990) 2004, 40(4):529-535.

22. Sawni A, Thomas R: Pediatricians' attitudes, experience and referral patterns regarding Complementary/Alternative Medicine: a national survey. BMC complementary and alternative medicine 2007, 7:18.

23. Lee RT, Hlubocky FJ, Hu JJ, Stafford RS, Daugherty CK: An international pilot study of oncology physicians' opinions and practices on Complementary and Alternative Medicine (CAM). Integrative cancer therapies 2008, 7(2):70-75.

24. Wu C, Weber W, Kozak L, Standish LJ, Ojemann JG, Ellenbogen RG, Avellino AM: A survey of complementary and alternative medicine (CAM) awareness among neurosurgeons in Washington State. Journal of alternative and complementary medicine (New York, NY) 2009, 15(5):551-555.

25. Manek NJ, Crowson CS, Ottenberg AL, Curlin FA, Kaptchuk TJ, Tilburt JC: What rheumatologists in the United States think of complementary and alternative medicine: results of a national survey. BMC complementary and alternative medicine 2010, 10:5.

26. Kundu A, Tassone RF, Jimenez N, Seidel K, Valentine JK, Pagel PS: Attitudes, patterns of recommendation, and communication of pediatric providers about complementary and alternative medicine in a large metropolitan children's hospital. Clinical pediatrics 2011, 50(2):153158.

27. Tempest H, Reynard J, Bryant RJ, Hamdy FC, Larre S: Acupuncture in urological practice-a survey of urologists in England. Complement Ther Med 2011, 19(1):27-31.

28. Vlieger AM, van Vliet M, Jong MC: Attitudes toward complementary and alternative medicine: a national survey among paediatricians in the Netherlands. European journal of pediatrics 2011, 170(5):619-624.

29. Samuels N, Zisk-Rony RY, Many A, Ben-Shitrit G, Erez O, Mankuta D, Rabinowitz R, Lavie O, Shuval JT, Oberbaum M: Use of and attitudes toward complementary and alternative medicine among obstetricians in Israel. International journal of gynaecology and obstetrics: the official organ of the International Federation of Gynaecology and Obstetrics 2013, 121(2):132-136.

30. Trimborn A, Senf B, Muenstedt K, Buentzel J, Micke O, Muecke R, Prott FJ, Wicker S, Huebner J: Attitude of employees of a university clinic to complementary and alternative medicine in oncology. Annals of oncology : official journal of the European Society for Medical Oncology 2013, 24(10):2641-2645.

31. Conrad AC, Muenstedt K, Micke O, Prott FJ, Muecke R, Huebner J: Attitudes of members of the German Society for Palliative Medicine toward complementary and alternative medicine for cancer patients. Journal of cancer research and clinical oncology 2014, 140(7):12291237.

32. Stewart D, Pallivalappila AR, Shetty A, Pande B, McLay JS: Healthcare professional views and experiences of complementary and alternative therapies in obstetric practice in North East Scotland: a prospective questionnaire survey. BJOG : an international journal of 
obstetrics and gynaecology 2014, 121(8):1015-1019.

33. Crundwell G, Baguley DM: Attitudes towards and personal use of complementary and alternative medicine amongst clinicians working in audiovestibular disciplines. The Journal of laryngology and otology 2016, 130(8):730-733.

34. Gaboury I, Johnson N, Robin C, Luc M, O'Connor D, Patenaude J, Pelissier-Simard L, Xhignesse M: Complementary and alternative medicine: Do physicians believe they can meet the requirements of the College des medecins du Quebec? Canadian family physician Medecin de famille canadien 2016, 62(12):e772-e775.

35. Soos SA, Jeszenoi N, Darvas K, Harsanyi L: Complementary and alternative medicine: attitudes, knowledge and use among surgeons and anaesthesiologists in Hungary. BMC complementary and alternative medicine 2016, 16(1):443.

36. Stone AB, Sheinberg R, Bertram A, Seymour AR: Are Anesthesia Providers Ready for Hypnosis? Anesthesia Providers' Attitudes Toward Hypnotherapy. The American journal of clinical hypnosis 2016, 58(4):411-418.

\section{Tables}

Table 1. Characteristics of the Included Studies 


\begin{tabular}{|c|c|c|c|c|c|c|c|c|c|}
\hline First author & Year & Country & Setting & $\begin{array}{l}\text { Sampling } \\
\text { method }\end{array}$ & $\begin{array}{l}\text { Survey } \\
\text { method }\end{array}$ & Response, \% & $\begin{array}{l}\text { Response, } \\
\mathrm{n}\end{array}$ & $\begin{array}{l}\text { Medical } \\
\text { Specialist, } \\
\text { n }\end{array}$ & Citation \\
\hline Rosenbaum & 2002 & USA & $\begin{array}{l}\text { The University } \\
\text { of lowa College } \\
\text { of Medicine }\end{array}$ & Random & Postal & $18.4 \%$ & 690 & 265 & [17] \\
\hline Hyodo & 2003 & Japan & $\begin{array}{l}\text { The Japanese } \\
\text { oncology } \\
\text { literature and } \\
\text { The Nationwide } \\
\text { association of } \\
\text { medical centers } \\
\text { for cancer and } \\
\text { adult diseases }\end{array}$ & Random & Postal & $66.7 \%$ & 54 & 52 & [18] \\
\hline Kemper & 2004 & USA & $\begin{array}{l}\text { The American } \\
\text { Academy of } \\
\text { Pediatrics }\end{array}$ & Random & Online & $19.5 \%$ & 195 & 195 & [19] \\
\hline Kolstad & 2004 & Norway & $\begin{array}{l}\text { Five university } \\
\text { oncology units } \\
\text { in Norway }\end{array}$ & Random & Postal & $38.5 \%$ & 751 & 751 & [20] \\
\hline Risberg & 2004 & Norway & $\begin{array}{l}\text { Five reginal } \\
\text { oncology } \\
\text { centers }\end{array}$ & Random & Postal & $15.4 \%$ & 104 & 104 & [21] \\
\hline Samano & 2005 & Brazil & $\begin{array}{l}\text { Effective } \\
\text { physician } \\
\text { members of the } \\
\text { Brazilian Cancer } \\
\text { Society }\end{array}$ & Random & Postal & $61.5 \%$ & 509 & 108 & [15] \\
\hline Sawni & 2007 & USA & $\begin{array}{l}\text { The American } \\
\text { Academy of } \\
\text { Pediatrics }\end{array}$ & Random & Postal & $31.5 \%$ & 268 & 263 & [22] \\
\hline Lee & 2008 & $\begin{array}{l}\text { USA, China, } \\
\text { and Taiwan }\end{array}$ & $\begin{array}{l}\text { The Northern } \\
\text { California } \\
\text { Tumor Board } \\
\text { meeting, China } \\
\text { Medical } \\
\text { University, Sun- } \\
\text { Yat Sen Cancer } \\
\text { Center Taiwan, } \\
\text { Peking } \\
\text { University } \\
\text { Cancer Hospital } \\
\text { China, and } \\
\text { Peking Union } \\
\text { Hospital China }\end{array}$ & Random & Postal & $38.0 \%$ & 95 & 95 & [23] \\
\hline Mak & 2009 & Australia & $\begin{array}{l}\text { The } \\
\text { Australasian } \\
\text { Faculty of } \\
\text { Rehabilitation } \\
\text { Medicine, The } \\
\text { Royal } \\
\text { Australasia } \\
\text { College of } \\
\text { Physicians }\end{array}$ & Random & Online & $38.3 \%$ & 36 & 36 & [14] \\
\hline Wu & 2009 & USA & $\begin{array}{l}\text { The } \\
\text { Washington } \\
\text { State of } \\
\text { Association of } \\
\text { Neurological } \\
\text { Surgeons }\end{array}$ & Random & Online & $67.0 \%$ & 65 & 65 & [24] \\
\hline Manek & 2010 & USA & $\begin{array}{l}\text { The Practicing } \\
\text { rheumatologists } \\
\text { in the United } \\
\text { States }\end{array}$ & Random & Postal & $40.3 \%$ & 381 & 381 & [25] \\
\hline Kundu & 2011 & USA & $\begin{array}{l}\text { The Seattle } \\
\text { Children's } \\
\text { Hospital }\end{array}$ & Random & Online & $43.7 \%$ & 213 & 213 & [26] \\
\hline
\end{tabular}




\begin{tabular}{|c|c|c|c|c|c|c|c|c|c|}
\hline First author & Year & Country & Setting & $\begin{array}{l}\text { Sampling } \\
\text { method }\end{array}$ & $\begin{array}{l}\text { Survey } \\
\text { method }\end{array}$ & Response, \% & $\begin{array}{l}\text { Response, } \\
\mathrm{n}\end{array}$ & $\begin{array}{l}\text { Medical } \\
\text { Specialist, } \\
\text { n }\end{array}$ & Citation \\
\hline Tempest & 2011 & England & $\begin{array}{l}\text { The urologist } \\
\text { practicing in } \\
\text { three English } \\
\text { training } \\
\text { deaneries }\end{array}$ & Random & $\begin{array}{l}\text { Online } \\
\text { and } \\
\text { Phone }\end{array}$ & $13.4 \%$ & 88 & 88 & [27] \\
\hline Vlieger & 2011 & Netherlands & $\begin{array}{l}\text { The Dutch } \\
\text { Society of } \\
\text { Paediatrics }\end{array}$ & Random & Online & $\begin{array}{l}\text { Not } \\
\text { indicated } \\
\text { denominator }\end{array}$ & 170 & 170 & [28] \\
\hline Samuels & 2013 & Israel & $\begin{array}{l}\text { Member of the } \\
\text { Obstetricians } \\
\text { and } \\
\text { gynecologists } \\
\text { (board-certified } \\
\text { specialists or } \\
\text { residents) were } \\
\text { recruited from } 7 \\
\text { medical centers } \\
\text { in Southern, } \\
\text { Central, and } \\
\text { Northern Israel }\end{array}$ & Convenience & $\begin{array}{l}\text { Not } \\
\text { indicated }\end{array}$ & $18.5 \%$ & 648 & 648 & [29] \\
\hline Trimborn & 2013 & Germany & $\begin{array}{l}\text { The German } \\
\text { employee } \\
\text { visiting the } \\
\text { occupational } \\
\text { health service } \\
\text { of the university } \\
\text { hospital }\end{array}$ & Convenience & $\begin{array}{l}\text { Not } \\
\text { indicated }\end{array}$ & $75.7 \%$ & 258 & 258 & [30] \\
\hline Conrad & 2014 & Germany & $\begin{array}{l}\text { The German } \\
\text { Society for } \\
\text { Palliative Care }\end{array}$ & Random & Online & $86.7 \%$ & 117 & 40 & [31] \\
\hline Stewart & 2014 & Scotland & $\begin{array}{l}\text { The care of } \\
\text { pregnant } \\
\text { women in the } \\
\text { Grampian } \\
\text { region of North- } \\
\text { East Scotland }\end{array}$ & Random & $\begin{array}{l}\text { Online } \\
\text { and } \\
\text { postal }\end{array}$ & $72.0 \%$ & 126 & 96 & [32] \\
\hline $\begin{array}{l}\text { Brambila- } \\
\text { Tapia }\end{array}$ & 2016 & Mexico & $\begin{array}{l}\text { The Primary } \\
\text { and secondary } \\
\text { care hospital in } \\
\text { Guadalajara }\end{array}$ & Convenience & $\begin{array}{l}\text { Not } \\
\text { indicated }\end{array}$ & $13.0 \%$ & 547 & 120 & [16] \\
\hline Crundwell & 2016 & UK & $\begin{array}{l}\text { The Clinical } \\
\text { staff working in } \\
\text { Cambridge } \\
\text { University } \\
\text { Hospital } \\
\text { otolaryngology } \\
\text { and audiology } \\
\text { departments }\end{array}$ & Convenience & $\begin{array}{l}\text { Not } \\
\text { indicated }\end{array}$ & $23.7 \%$ & 343 & 343 & [33] \\
\hline Gaboury & 2016 & Canada & $\begin{array}{l}\text { The College des } \\
\text { medecins du } \\
\text { Quebec }\end{array}$ & Random & Online & $100.0 \%$ & 207 & 107 & [34] \\
\hline Mann & 2016 & USA & $\begin{array}{l}\text { The American } \\
\text { College of } \\
\text { Graduate } \\
\text { Medical } \\
\text { Education pain } \\
\text { medicine } \\
\text { fellowship }\end{array}$ & Convenience & $\begin{array}{l}\text { Online } \\
\text { and } \\
\text { postal }\end{array}$ & $53.3 \%$ & 856 & 856 & [13] \\
\hline Soos & 2016 & Hungary & $\begin{array}{l}\text { Four Hungarian } \\
\text { universities and } \\
\text { other eleven } \\
\text { surgery wards } \\
\text { and intensive } \\
\text { care } \\
\text { departments } \\
\text { participated }\end{array}$ & Convenience & $\begin{array}{l}\text { Online } \\
\text { and } \\
\text { postal }\end{array}$ & $61.5 \%$ & 509 & 101 & [35] \\
\hline
\end{tabular}




\begin{tabular}{|c|c|c|c|c|c|c|c|c|c|}
\hline First author & Year & Country & Setting & $\begin{array}{l}\text { Sampling } \\
\text { method }\end{array}$ & $\begin{array}{l}\text { Survey } \\
\text { method }\end{array}$ & Response, \% & $\begin{array}{l}\text { Response, } \\
\mathrm{n}\end{array}$ & $\begin{array}{l}\text { Medical } \\
\text { Specialist, } \\
\text { n }\end{array}$ & Citation \\
\hline Stone & 2016 & Australia & $\begin{array}{l}\text { All faculty, } \\
\text { fellows, and } \\
\text { residents } \\
\text { present at a } \\
\text { single } \\
\text { anesthesia } \\
\text { grand rounds of } \\
\text { Johns Hopkins } \\
\text { University }\end{array}$ & Random & $\begin{array}{l}\text { Not } \\
\text { indicated }\end{array}$ & $70.3 \%$ & 102 & 102 & [36] \\
\hline Klein & 2017 & Germany & $\begin{array}{l}\text { The Research } \\
\text { Group on } \\
\text { Gynecological } \\
\text { Oncology of the } \\
\text { German Cancer } \\
\text { Society }\end{array}$ & Random & Online & $38.1 \%$ & 24 & 24 & [12] \\
\hline
\end{tabular}

Table 2. The number of medical specialists according to the American Board of Medical Specialties.

\begin{tabular}{|llll|}
\hline No. & $\begin{array}{l}\text { American Board of } \\
\text { Medical Specialties }\end{array}$ & Studies & Participants \\
\hline 1 & Allergy and Immunology & - & - \\
\hline 2 & Anesthesiology & 4 & 342 \\
\hline 3 & Colon and Rectal Surgery & - & - \\
\hline 4 & Dermatology & - & - \\
\hline 5 & Emergency Medicine & - & - \\
\hline 6 & Family Medicine & 3 & 296 \\
\hline 7 & Internal Medicine & 11 & 2,108 \\
\hline 8 & Medical Genetics and Genomics & - & - \\
\hline 9 & Neurological Surgery & 1 & 24 \\
\hline 10 & Nuclear Medicine & - & - \\
\hline 11 & Obstetrics and Gynecology & 5 & 326 \\
\hline 12 & Ophthalmology & - & - \\
\hline 13 & Orthopaedic Surgery & - & - \\
\hline 14 & Otolaryngology - Head and Neck Surgery & 1 & 49 \\
\hline 15 & Pathology & - & - \\
\hline 16 & Pediatrics & 6 & 2,130 \\
\hline 17 & Physical Medicine and Rehabilitation & 3 & 104 \\
\hline 18 & Plastic Surgery & - & - \\
\hline 19 & Preventive Medicine & - & - \\
\hline 20 & Psychiatry and Neurology & - & 22 \\
\hline 21 & Radiology & - & - \\
\hline 22 & Surgery & -965 \\
\hline 23 & Thoracic Surgery & - \\
\hline 24 & Urology & - & - \\
\hline Total & & - & - \\
\hline
\end{tabular}

Page $12 / 19$ 
Table 3. Subgroup analysis

\begin{tabular}{|c|c|c|c|}
\hline Subgroup & $\begin{array}{l}\text { No. of studies } \\
\text { (no. of MS) }\end{array}$ & Difference in pooled prevalence $(95 \% \mathrm{Cl})$ & p-value \\
\hline \multicolumn{4}{|l|}{ CAM Acceptance } \\
\hline \multicolumn{4}{|l|}{ Region } \\
\hline - $\quad$ Region of the Americas & $5(842)$ & $0.00(-0.28,0.27)$ & 0.979 \\
\hline - $\quad$ European Region & $5(846)$ & $0.10(-0.16,0.36)$ & 0.405 \\
\hline - Western Pacific Region & $2(787)$ & $-0.18(-0.51,0.16)$ & 0.271 \\
\hline \multicolumn{4}{|l|}{ Sampling method } \\
\hline - $\quad$ Random sampling & 9 (2032) & $-0.01(-0.32,0.30)$ & 0.943 \\
\hline \multicolumn{4}{|l|}{ CAM Usage } \\
\hline \multicolumn{4}{|l|}{ Region } \\
\hline - $\quad$ Region of the Americas & $8(2435)$ & $0.12(-0.08,0.31)$ & 0.222 \\
\hline - $\quad$ European Region & $9(1460)$ & $0.04(-0.16,0.24)$ & 0.706 \\
\hline - Western Pacific Region & $3(883)$ & $-0.17(-0.45,0.10)$ & 0.204 \\
\hline - $\quad$ Mixed region & $1(95)$ & $-0.36(-0.79,0.07)$ & 0.098 \\
\hline \multicolumn{4}{|l|}{ Economic levels of country } \\
\hline - $\quad$ Upper-middle-income economies & 2 (195) & $0.24(-0.08,0.56)$ & 0.133 \\
\hline - $\quad$ High-income economies & $18(4583)$ & $-0.03(-0.32,0.25)$ & 0.804 \\
\hline - $\quad$ Mixed-income economies & $1(95)$ & $-0.36(-0.79,0.07)$ & 0.098 \\
\hline \multicolumn{4}{|l|}{ Sampling method } \\
\hline - $\quad$ Random sampling & $15(4101)$ & $-0.03(-0.25,0.19)$ & 0.802 \\
\hline
\end{tabular}

Figures 


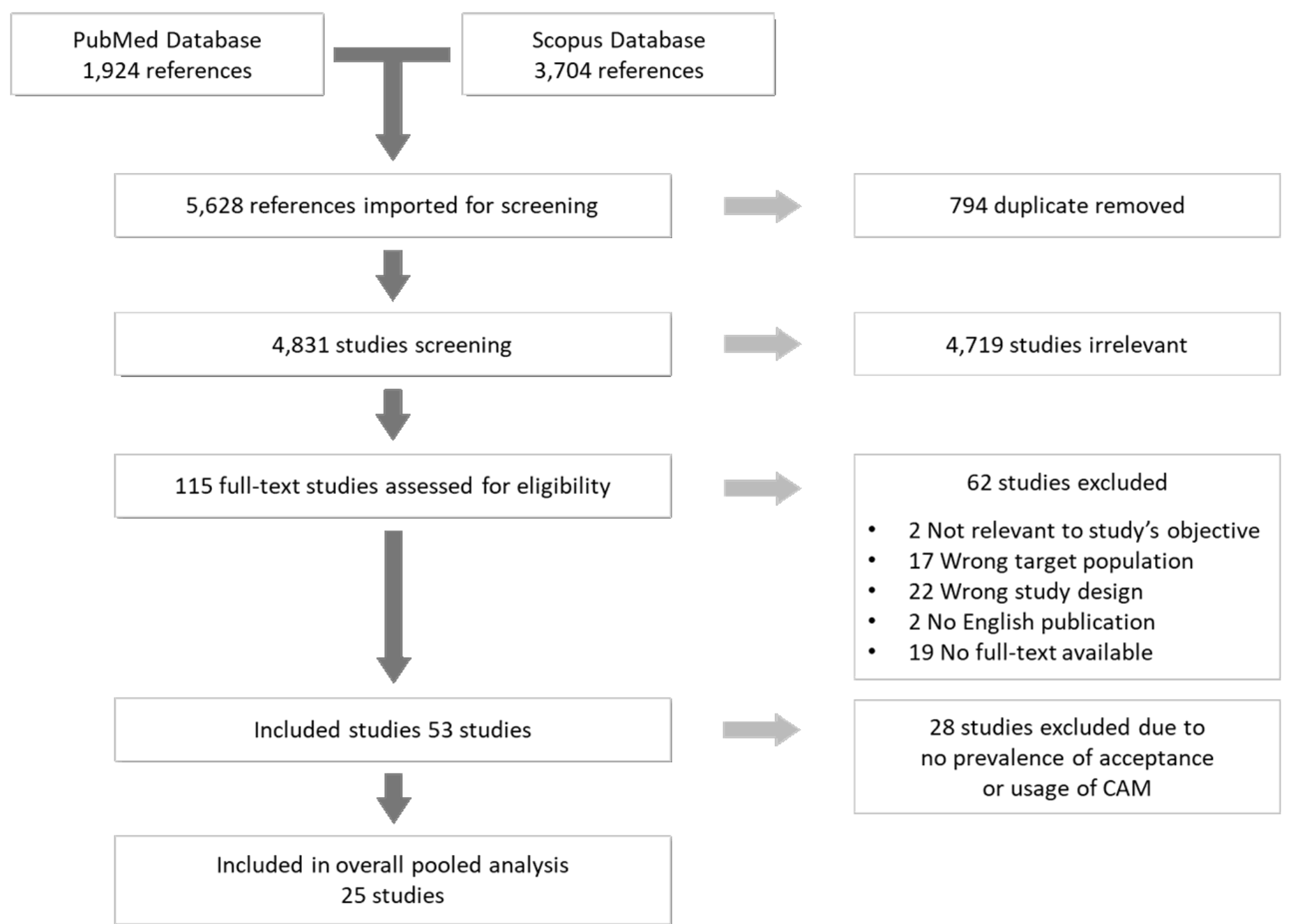

Figure 1

Selection of the studies. 


\section{Forest Plot of CAM Acceptance by Specialty}

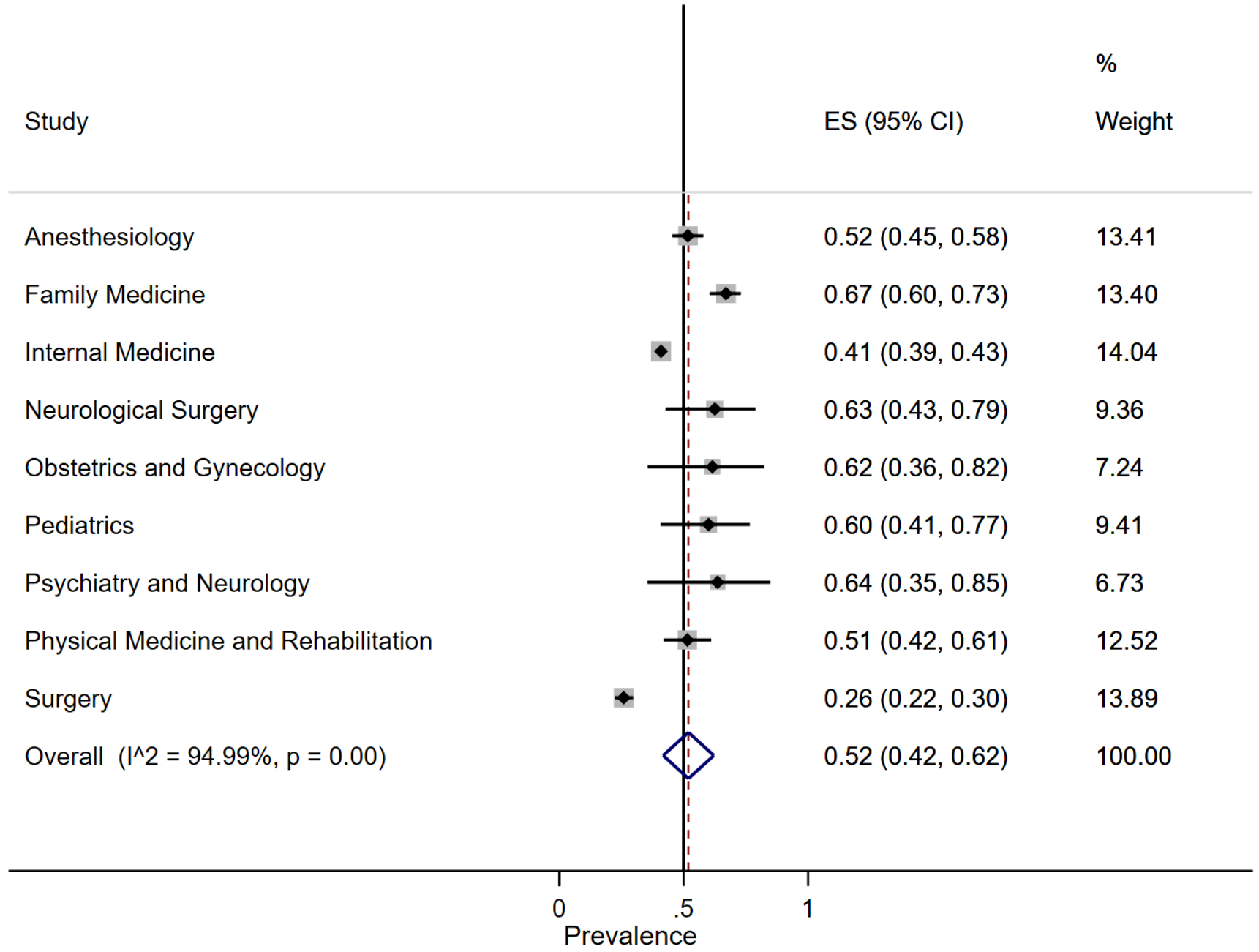

Figure 2

Forest plot of CAM acceptance by specialty. 


\section{Forest Plot of CAM Usage by Specialty}

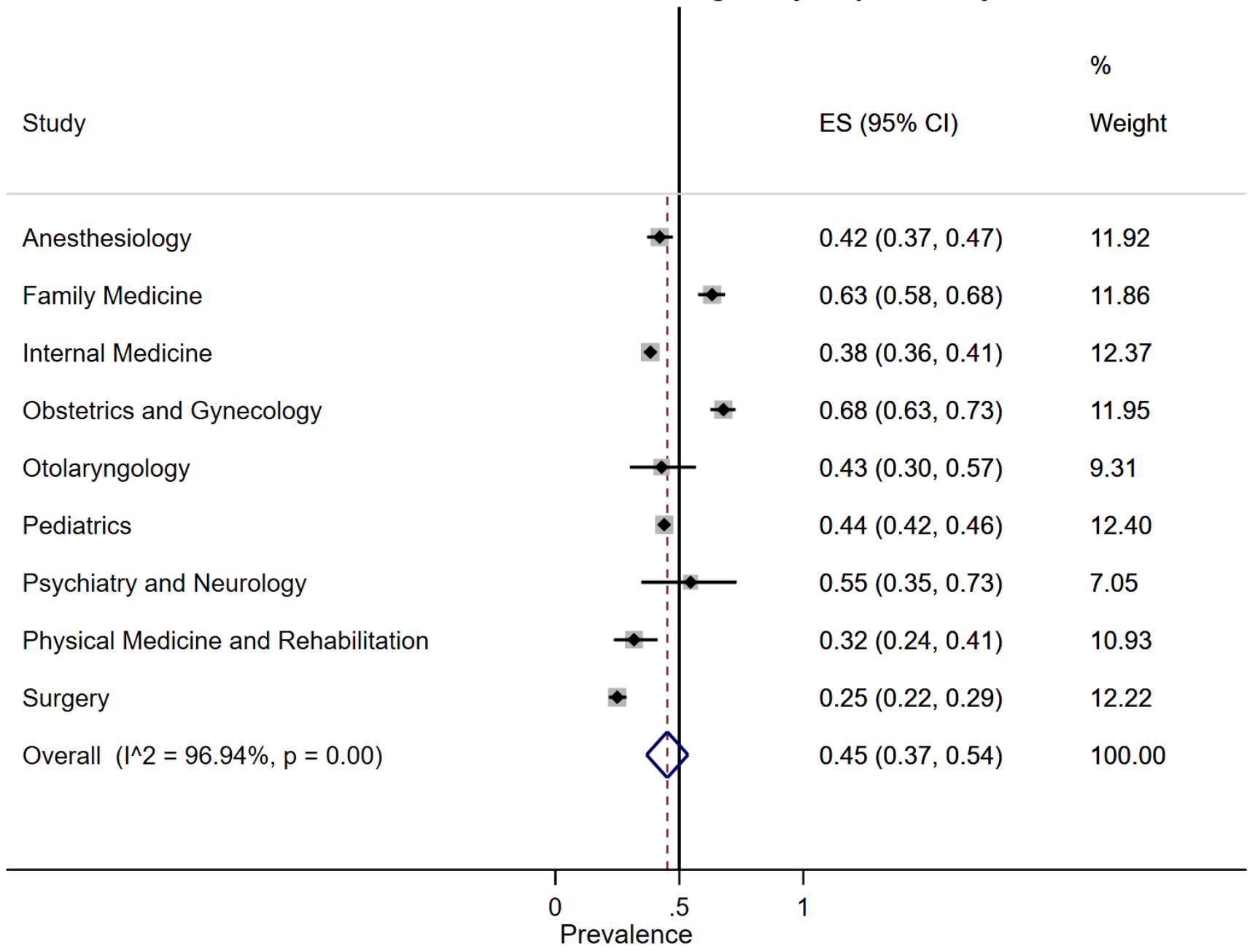

Figure 3

Forest plot of CAM usage by specialty. 
Forest Plot of CAM Acceptance
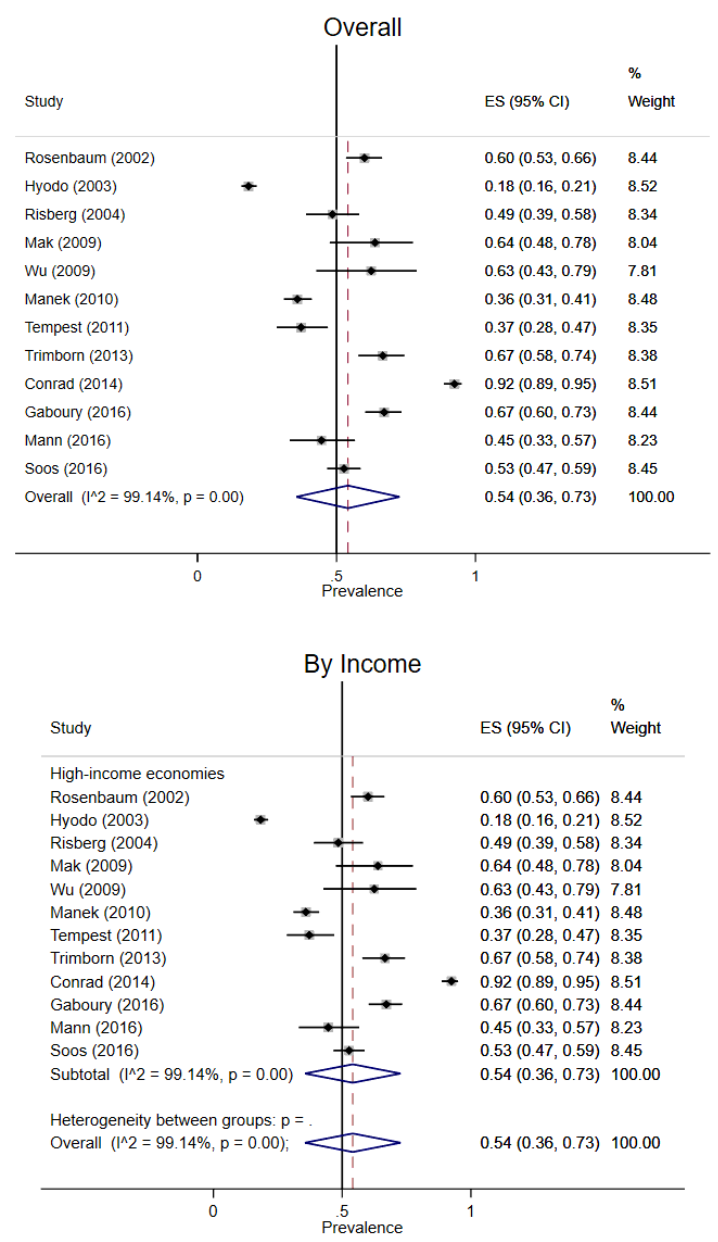
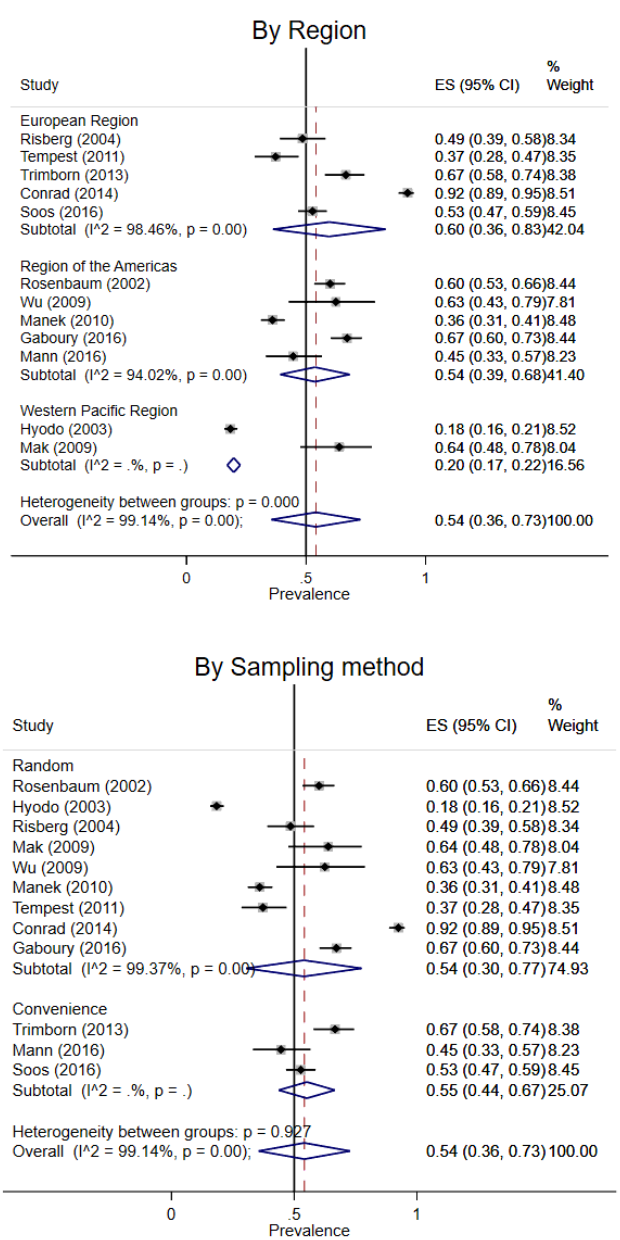

Figure 4

Forest plot of CAM acceptance. 


\section{Forest Plot of CAM Usage}
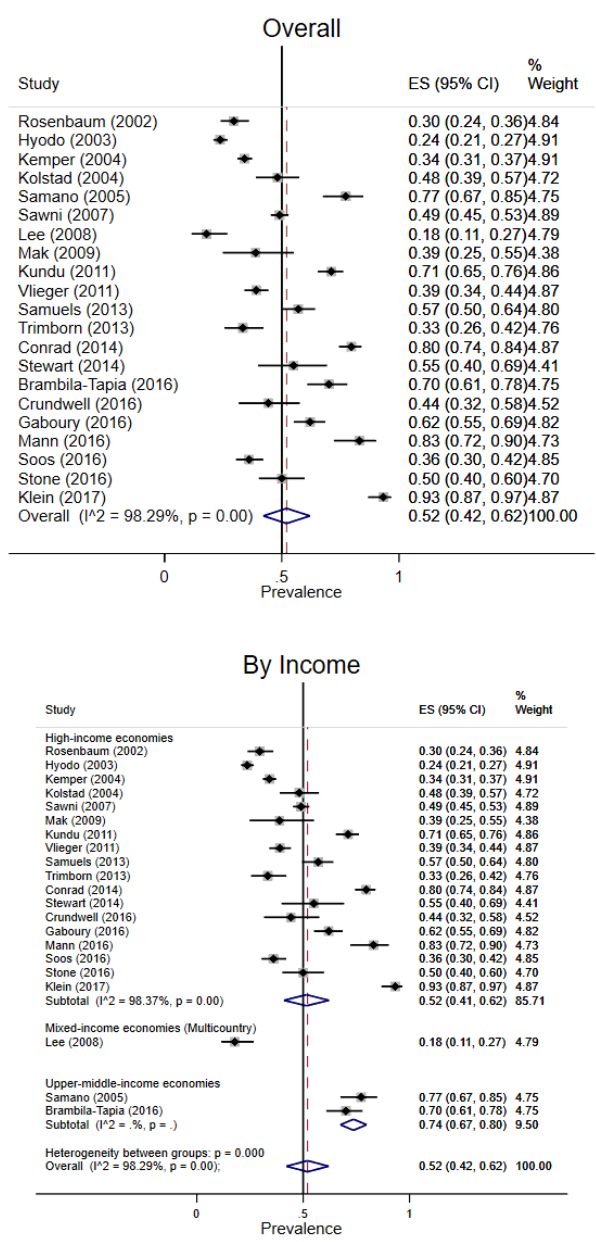

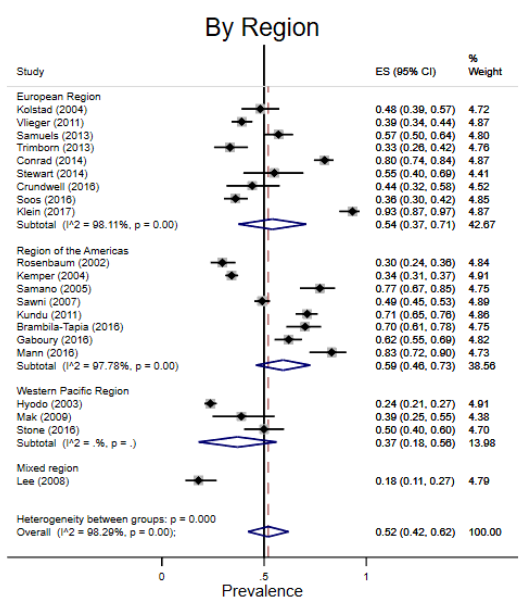

By Sampling method

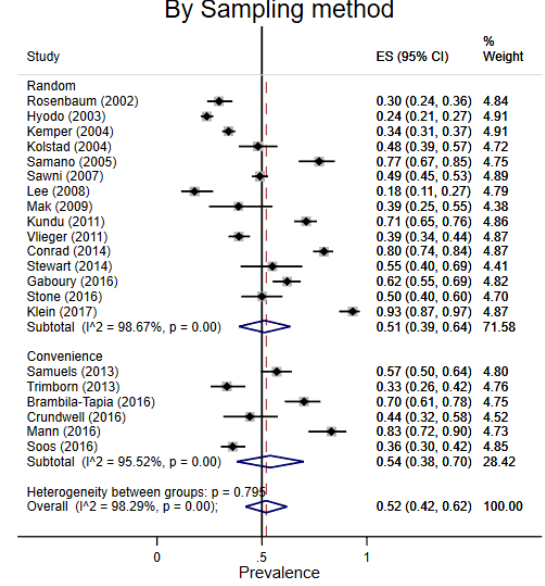

Figure 5

Forest plot of CAM usage. 


\begin{tabular}{|c|c|c|c|c|c|c|c|c|c|c|c|c|}
\hline St & 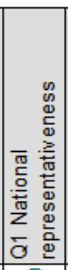 & 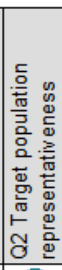 & 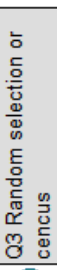 & 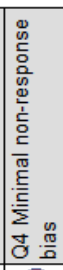 & 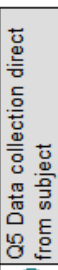 & 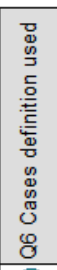 & 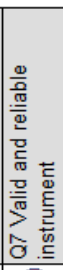 & 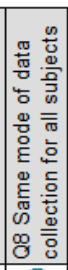 & 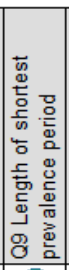 & 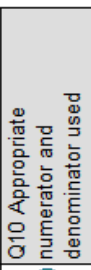 & 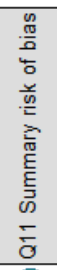 & \\
\hline Qosenbaum & 4 & 4 & 4 & $\boldsymbol{\theta}$ & 4 & 4 & $\theta$ & 4 & 4 & 4 & 4 & \\
\hline odo & 4 & 4 & 4 & $\theta$ & 4 & 4 & $\boldsymbol{\theta}$ & 4 & 4 & (4) & 4 & \\
\hline Semper (20104) & 4 & 4 & 4 & C & 4 & 4 & $\Theta$ & 4 & 4 & C & 4 & \\
\hline Catstad (21.14) & 4 & 4 & 4 & - & 4 & 4 & $\theta$ & 4 & 4 & 4 & 4 & \\
\hline iste & 4 & 4 & 4 & - & 4 & 4 & - & 4 & 4 & $(4$ & 4 & \\
\hline$m e$ & 4 & 4 & 4 & $\theta$ & 4 & 4 & $\theta$ & 4 & 4 & 4 & 4 & \\
\hline Sami & 4 & 4 & 4 & $\Theta$ & 4 & 4 & $\theta$ & 4 & 4 & $\theta$ & 4 & \\
\hline 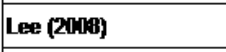 & 4 & 4 & 4 & $\boldsymbol{\theta}$ & 4 & 4 & - & 4 & 4 & 4 & 4 & \\
\hline lak 0 & 4 & 4 & 4 & $\boldsymbol{\theta}$ & 4 & 4 & $\boldsymbol{\theta}$ & 4 & 4 & $\boldsymbol{\theta}$ & 4 & \\
\hline Nu (21019) & 4 & 4 & 4 & $\boldsymbol{\theta}$ & 4 & 4 & $\theta$ & 4 & 4 & 4 & 4 & \\
\hline Vanet & 4 & 4 & 4 & C & 4 & 4 & $\Theta$ & 4 & 4 & 4 & 4 & \\
\hline Gund & 4 & 4 & 4 & C & 4 & 4 & - & 4 & 4 & 4 & 4 & \\
\hline Tempes & 4 & 4 & 4 & C & 4 & 4 & $\theta$ & 4 & 4 & 4 & 4 & \\
\hline Neyer of & 4 & 4 & 4 & C & 4 & 4 & $\theta$ & 4 & 4 & - & 4 & 1 \\
\hline Bamue & 4 & 4 & $\theta$ & $\boldsymbol{\theta}$ & 4 & 4 & $\theta$ & 4 & 4 & 4 & 4 & \\
\hline Inimbo & (4) & 4 & 4 & $\boldsymbol{\theta}$ & 4 & 4 & $\theta$ & 4 & 4 & 4 & 4 & \\
\hline Comrad & (4) & 4 & 4 & & 4 & 4 & $\theta$ & 4 & 4 & (4) & 4 & \\
\hline Stewr. & 4 & 4 & 4 & & 4 & 4 & 4 & 4 & 4 & 4 & 4 & \\
\hline Gram & 4 & 4 & $\theta$ & & 4 & 4 & $\theta$ & 4 & 4 & 4 & 4 & \\
\hline Cound & 4 & $\theta$ & $\theta$ & ( & $\theta$ & 4 & 4 & $\theta$ & 4 & 4 & & \\
\hline Gabout & (4) & 4 & 4 & ? & 4 & 4 & 4 & 4 & 4 & $\theta$ & 4 & \\
\hline Mam & (4) & 4 & 0 & D & 4 & 4 & $\theta$ & 4 & 4 & 4 & 4 & $=$ \\
\hline Soos & 4 & 4 & $\theta$ & $\theta$ & 4 & 4 & $\boldsymbol{\theta}$ & 4 & 4 & 4 & 4 & $=$ \\
\hline Stan: & (4) & 4 & 4 & $\boldsymbol{\theta}$ & 4 & (4) & $\boldsymbol{\theta}$ & 4 & 4 & 4 & 4 & $\theta$ \\
\hline $\operatorname{len}(2017)$ & (4) & 4 & 4 & $\Theta$ & 4 & 4 & $\Theta$ & 4 & 4 & (4) & 4 & C \\
\hline
\end{tabular}

Figure 6

Study quality/risk of bias of the included studies.

\section{Supplementary Files}

This is a list of supplementary files associated with this preprint. Click to download.

- GraphicalAbstract.pdf

- AdditionalFile1.docx 